\title{
THE PALAEOGEOGRAPHIC DISTRIBUTION OF STROMATOLITES IN THE PARNASSUS ZONE, CENTRAL GREECE, DURING THE EARLY TO MIDDLE PALEOCENE
}

\author{
N. SOLAKIUS ${ }^{1}$ AND M. KATI ${ }^{2}$
}

\begin{abstract}
The stromatolites recorded in the Parnassus Zone, central Greece, were developed in shallow waters (tidal flat conditions) that prevailed in the central areas of the zone during the early to middle Paleocene. In the margins, deeper water prevailed during this interval which enabled the deposition of pelagic limestones. The wide geographic distribution of the stromatolites in the zone probably depended on the lack of organisms feeding on them, climatic factors, salinity of coastal waters and sediment supply. They further acted as post massextinction disaster forms inhabiting the shallow water areas after the extinction of the rudists at the end of the Cretaceous.
\end{abstract}

KEY WORDS: Parnassus zone, Paleocene, stromatolites

\section{INTRODUCTION}

It has previously been shown that the stromatolites in the Parnassus Zone, Central Greece (Fig. 1), developed during the early to middle Paleocene above phosphatic hardground beds formed on the top of the Cretaceous carbonate substrate (Kalpakis, 1979; Solakius et al., 1989; Solakius, 1994; Pomomi-Papaioannou, 1994). These hardgrounds have resulted from breaks in deposition during the late Maastrichtian to earliest Paleocene in a seafloor temporarily emerged (Pomoni-Papaioannou, 1994; Solakius, 1994). Both the stromatolites and the underlying hardground bed have been mineralized by iron-oxides and phosphates and are often treated together as a unit termed the hardground-stromatolitic unit (Gregou \& Solakius, 1997).

The first more detailed study on the classification of the stromatolites and their habitat was carried out by Kalpakis (1979) who showed that they were of type SH (stacked hemispheroids) and type LLH (lateral linked hemispheroids) as well as knolls and they had developed in a shallow-water environment during the Paleocene. Pomoni-Papaioannou (1994) pointed out that they inhabited the ridges of an uneven seafloor covered by shallow waters on which condensed sedimentation took place and which periodically emerged. Chalks rich in phosphate lags accumulated in depressions. Gregou \& Solakius (1997) showed that the stromatolites were developed during the early to middle Paleocene (probably until early late Paleocene, Distomon area) both on ridges and in broad valleys while in the small depressions calcarenitic sediments were deposited.

Thus the stromatolites were shallow-water forms inhabited intertidal areas during the early to middle Paleocene. The questions arise: (a) Did the stromatolites inhabited a few restricted areas only or did they extend over large parts of the zone. (b) Were the environmental conditions in these areas unattractive for benthic invertebrates or did the stromatolites colonize shallow-water areas as post-mass-extinction disaster forms after the Cretaceous-Paleocene boundary crisis. In this paper we will present results on the paleogeographic distribution of the stromatolites in the Parnassus Zone together with a brief discussion on the environments that prevailed during the Paleocene and which enabled the stromatolites, as opportunistic organisms, to develop.

1. Department of Physical Geography, Lund University, S $\varphi$ lvegatan 13, SE-22362 Lund, Sweden

2. University of Athens, Department of Geology, Panepistimiopolis, 15784 Athens, Greece 

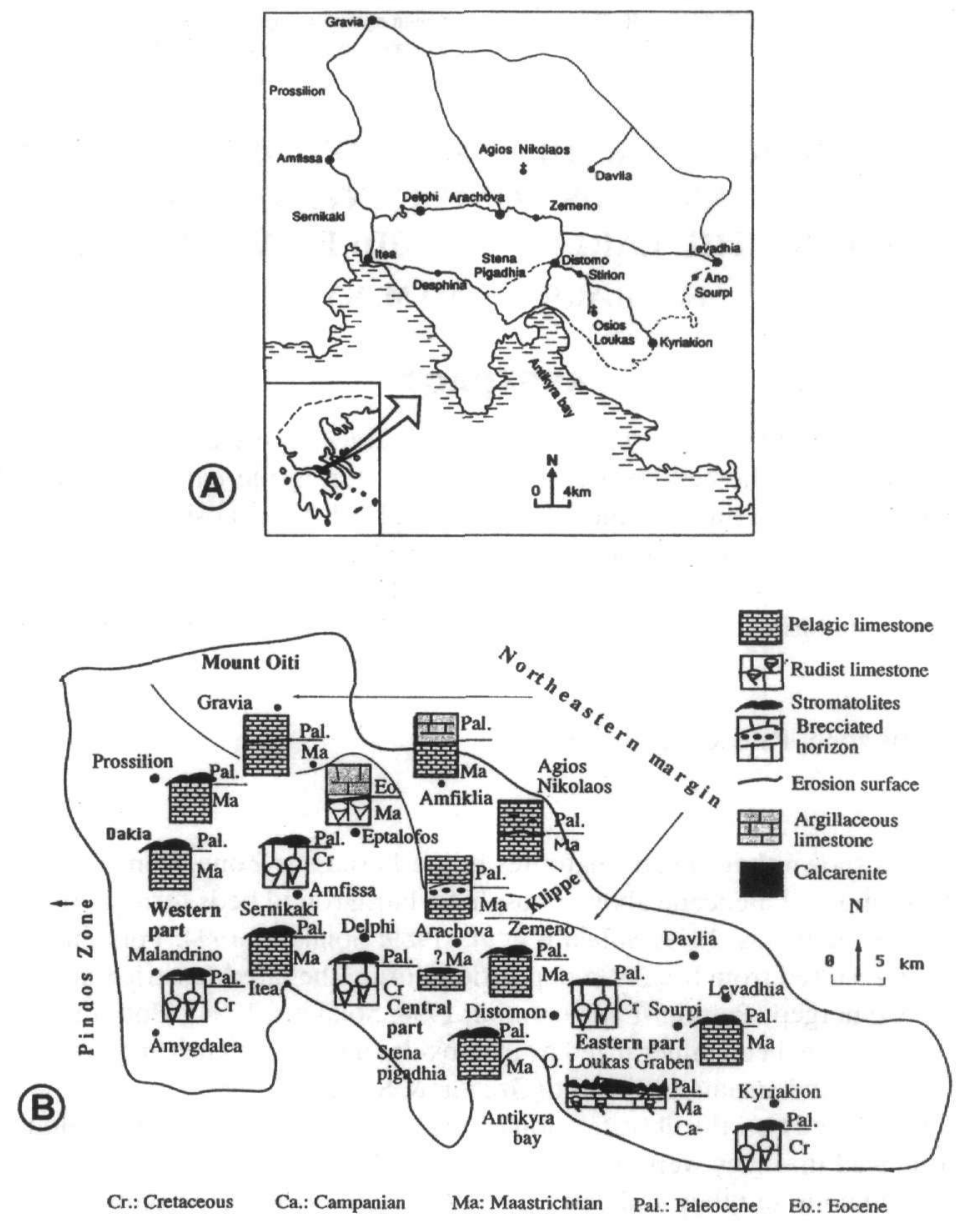

Fig. 1. A. Simplified map of Parnassus showing the position of the areas discussed. B. Localities treated in the text.

\section{THE PALAEOGEOGRAPHIC DISTRIBUTION OF THE STROMATOLITES IN THE PARNASSUS ZONE}

These stromatolites, type SH, type LLH and knolls, inhabited tidal flats. They overlie discontinuity surfaces, indicating the end of a regressive phase. The retreat of the sea brought about a change in morphology, the SH forms (intertidal zone) being replaced by LLH forms (supratidal) and finally by knolls.

The localities from which these stromatolites have been recorded, as well as the marginal areas in which carbonate deposition prevailed during the Paleocene, are presented below.

Western part of the zone (Fig. 2)

We found stromatolites close to the villages of Sernikaki and Prossilion, above pelagic limestones of late Maastrichtian age (Solakius et al., 1989; Pomoni-Papaioannou \& Solakius, 1991). Kalpakis (1979) reported the presence of stromatolites in the village of Dakia situated close to the city of Amfissa, not far from the village of Prossilion. Close to Malandrino and at Chrisso (close to the village of Delphi), well-developed stromatolitic crusts occur above the limestone substratum. Richter et al., (1995) described the stromatolites at Chrisso as "phosphoritishe-knollen". Stromatolites occur in the vicinity of the village of Amfissa (Sfagia) as well as east and north of the village of Prossilion while in the area close to Gravia Paleocene carbonates overlie the Cretaceous carbonate substrate. The above evidence indicates that the western part of the zone was inhabited by stromatolites except in its northeastern part where pelagic limestones were deposited. The wide distribution of stromatolites in the area, thus, proves that a very shallow marine environment (tidal flat conditions) prevailed. The foraminiferal 
assemblages trapped in the stromatolites indicate early to middle Paleocene age (Solakius et al., 1992). In the northeastern part of the area, however, the sea was deeper and here the Cretaceous deposition of carbonates continued throughout the early and middle Paleocene with a short interruption during the K-T boundary.

\section{Central part of the zone (Fig. 2)}

In the central part of the zone stromatolites recorded in the Distomon - Davlia area above rudist limestone beds, while at Zemeno they overlie Maastrichtian limestones. In a locality south of the village of Arachova first Keupp (1976) and subsequently Tselepidis (IGME, personal communication) reported the presence of calcarenite in a small depression. In the area southwest of Distomon (Stena Pigadhia) well-developed stromatolites appear above Maastrichtian limestone, while at Stirion, southeast of Distomon, stromatolites are found above rudist limestones.

Northeast of the village of Arachova, close to the old bridge, Paleocene carbonate formations overlie the Cretaceous substrate. According to Combes (1983) they form part of a klippe situated between the villages of Arachova and Davlia. This thrust sheet originated from the north-eastern margin of the Parnassus Zone (Gregou et al., 1994; Solakius et al., 1998). In the Amfiklia area, north of Arachova, however, the Cretaceous limestone beds are overlain by argillaceous limestones deposited during the Paleocene.

The occurrence of stromatolites indicates a tidal-flat environment in the central parts while the carbonate deposits recorded in the Amfiklia-Arachova-Agios Nikolaos points to deep- water deposition. As in the western part of the zone the foraminiferal assemblages recorded from both stromatolites and limestone beds, provide evidence that the stromatolites developed during the early and middle Paleocene, the deposition of the carbon-
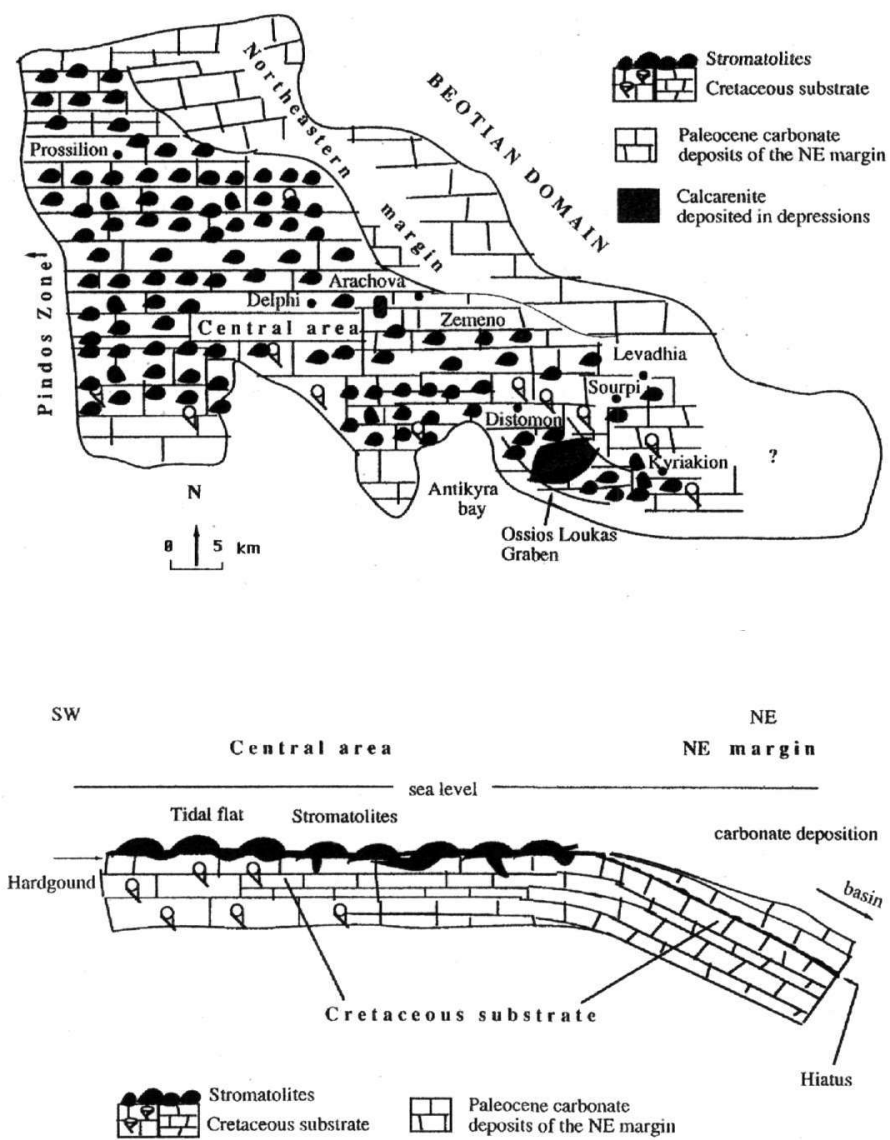

Fig. 2. A. Palaeogeographic distribution of stromatolites in the Parnassus Zone during early to middle Paleocene. B. SW-NE cross-section showing the shallow- and deep-water areas. 
ates in the Amfiklia-Arachova - Agios Nikolaos areas having taken place on the north-eastern margin at the same time.

\section{Eastern part of the zone}

In the Ossios Loukas - Kyriakion and the Sourpi areas stromatolites occur above the Cretaceous pavement except in the depression of the Ossios Loukas Graben where calcarenitic sediments were deposited (Gregou \& Solakius, 1997). The foraminiferal assemblages from the stromatolitic layers indicate that tidal flat environments prevailed in these areas during the early and middle Paleocene. The stromatolites in the Ossios Loukas Graben developed in an intertidal zone (Kalpakis, 1979) while the deposition of the calcarenite took place in deeper water (subtidal zone). Here it must be noted that in Ano Sourpi, Maastrichtian limestones are overlain by Paleocene carbonates indicating deeper water by contrast with the conditions in the eastern part of the zone during early to middle Paleocene times.

\section{CONCLUDING REMARKS}

Our results thus show that during the early to middle Paleocene, stromatolites developed in a shallow marine environment in central areas of the zone, while along the margins carbonates were deposited in deeper water. (Here it should be noted that the transitional formations of the western part of the Parnassus Zone into the Pindos Zone (Vardousia sub-zone) would be treated in a forthcoming paper). The results yield further evidence that the palaeotopographic highs and the shallow-water areas (horsts), as well as the deep-water areas (grabens), i.e. horst and grabens topography, which prevailed in the zone during the Late Cretaceous were replaced at the beginning of the Paleocene by a relatively flat seafloor in the central part and deeper marginal areas. This was resulted of the exposure and subsequent extensive karstification of the Cretaceous substrate after the fall in sea level in combination with uplift of the zone during late Maastrichtian to earliest Paleocene times (K-T boundary). Only the small depressions in the central part and along the margins remained under water during this interval.

The stromatolites first began to develop during the early Paleocene in the very shallow water of areas situated close to the depressions or flat coastal areas which were affected by tides. These flat areas constituted the bottoms of the Cretaceous grabens. Dry land representing former horsts provided protection where stromatolites could develop, as in the Ossios Loukas Graben. Broad valleys (composed by pelagic limestone beds) on both sides of the depression with the palaeotopographic highs of Distomon and Kyriakion (composed by rudist limestone beds)(Fig. 2) provided the most ideal setting for the stromatolites to develop. In his study of the Ossios Loukas stromatolites Kalpakis (1979) showed that intertidal conditions prevailed in these valleys. In the depressions in which calcarenite was deposited pointing out to subtidal conditions and in the area close to Stirion supratidal conditions prevailed.

Other protected habitats during the early Paleocene were the Sernikaki-Prossilion area in the western part of the zone, the Zemeno area in the central part and the Sourpi area to the east. As in the Ossios Loukas area the stromatolites developed above the Maastrichtian pelagic limestone beds that is the floors of the former Cretaceous grabens which during the Paleocene became shallow-water areas. During the middle Paleocene the sea level rose in central Parnassus causing even the higher parts to be inundated. The stromatolites invaded these areas conditions being favourable for their development whereas in the deeper areas they ceased to grow.

The abundance of stromatolites in central Parnassus was, apart from the shallow-water conditions, probably also determined by the lack of organisms feeding on them, climatic factors, the salinity of coastal waters and sediment supply. These organisms are further known to opportunistically take over in shallow-water habitats (Shcubert \& Bottjer, 1992) where other organisms have died out. During the Late Cretaceous the shallow-water areas of the Parnassus Zone were occupied by the rudists which became extinct at the end of this period. At the beginning of the Paleocene such a biotic void arose in these areas since they were probably unattractive to benthic invertebrates because of phosphatization, high salinity and iron-oxide deposition. These conditions persisted throughout the early and middle Paleocene. The subsidence of the zone during the late Paleocene (Solakius, 1994) led to the disappearance of the stromatolites from Parnassus and gave rise to the deposition of the preflysch sediments (Gregou \& Solakius, 1997).

\section{ACKNOWLEDGEMENTS}

The authors would like to thank Mrs Margaret Greenwood-Petersson for the linguistic revision of the paper.

\section{REFERENCES}


COMBES, P.J. 1983. Découverte d’une nouvelle nappe d’origine nord-orientale dans la zone du Parnasse, Gréce. Comptes Rendus de l'Academie des Sciences de Paris 296 II, 397-400. Paris.

GREGOU, S. \& SOLAKIUS, 1997. The pre-flysch and the basal shaly flysch deposition in Osios Loukas and Distomon areas, central Parnassus, central Greece, during the late Paleocene to early Eocene. Neues Jahrbuch für Geologie und Paläontologie Abhandlungen 204 (1), 35-82.Stuttgart.

GREGOU, S., SOLAKIUS, N. \& POMONI-PAPAIOANNOU, F. 1994. The carbonate-flysch transition in the Arachova sequence of the Parnassus-Ghiona Zone, Central Greece. Geological Magazine 131, 819-836. Cambridge.

KALPAKIS, G. 1979. Contribution à l’étude sédimentologique de la zone Parnasse-Kiona. Biomicrites, stromatolites, horizon hard grounds à la limite du Cretacé-Paléocène. $\mathrm{Ph}$. D. Thesis, University of Athens, Greece. Athens.

KEUPP, H. 1976. Tektonik und präorogene Stratigraphie der Flysch Depression von Delphi-Arachova (ParnassKiona-Zone, Mittelgriechenland. Zeitschrift Deutsches Geologische Geselschaft 127, 399-415. Berlin.

POMONI-PAPAIOANNOU, F. 1994. Paleoenvironmental reconstruction of a condensed hardground-type depositional sequence at the Cretaceous-Tertiary contact in the Parnassus-Ghiona zone, central Greece. Sedimentary Geology 93,7-24.

POMONI-PAPAIOANNOU, F. \& SOLAKIUS, N. 1991. Phosphatic hardground and stromatolites from the limestone/shale boundary section at Prossilion (Maastrichtian-Paleocene) in the Parnassus-Ghiona Zone, central Greece. Paleogeography, Paleoclimatology, Palaeoecology 86, 243-254. Amsterdam.

RICHTER, D., MÜLLER, C., HOTTINGER, L. \& RISCH, H. 1995. Die flysch-Zonen Greichenlands X. Neue daten zur Stratigraphie und Paläogeographie des Flysches und seiner Unterlage in Giona-Parnass-ElikonGebirge (Parnass-Zone, Griechenland. Neues Jahrbuch für Geologie und Paläontologie Abhandlungen 197, 295-329. Stuttgart

SCHUBERT, J. \& BOTTJER, D. 1992. Early Triassic stromatolites as post-mass extinction disaster forms. Geology 20,883-886. Boulder.

SOLAKIUS, N. 1994. depositional changes in the Parnassus-Ghiona Zone, Central Greece, during the Paleocene. Bulletin of the Geological Society of Greece 30, 201-205. Athens.

SOLAKIUS, N., POMONI-PAPAIOANNOU, F. \& MARANGOUDAKIS, N. 1989. Planktic foraminiferal biostratigraphy and sedimentology of the Cretaceous-Tertiary boundary in the Sernikaki section (The Parnassus-Ghiona Zone, central Greece. Revista Espanola de Micropaleontologia 12, 373-389. Madrid.

SOLAKIUS, N., LARSSON, K. \& POMONI-PAPAIOANNOU, F. 1992. Planktic foraminiferal biostratigraphy of the carbonate/flysch transitional beds at Prossilion, in the Parnassus-Ghiona Zone, Central Greece. Acta Geologica Hungarica 35, 441-445. Budapest.

SOLAKIUS, N., CARRAS, N., MAVRIDIS, A., POMONI-PAPAIOANNOU, F. \& GREGOU, S. 1998. Late Cretaceous to early Paleocene planktonic foraminiferal stratigraphy of the Agios Nikolaos sequence, the Parnassus-Ghiona Zone, central Greece. Bulletin of the Geological Society of Greece 32, 13-20. Athens. 